\title{
Nutritional Properties, Antioxidant and Enzyme Inhibitory Activities of Bread Sweetened with Date Fruit
}

\author{
Albert Akinsola Famuwagun ${ }^{1, a, *}$, Saka Olasunkanmi Gbadamosi ${ }^{1, b}$ \\ ${ }^{I}$ Department of Food Science and Technology, Obafemi Awolowo University, Ile-Ife, Nigeria \\ *Corresponding author

A R T I C L E I N F O A B S T R A C T \\ Research Article \\ The study investigated the potentials of date fruit as sweetening agent in bread and determined \\ micronutrient composition, antioxidant properties and inhibition of diabetic related enzymes such \\ as the alpha amylase and glucosidase. The fibre and ash contents of the samples increased with the \\ addition of date fruit. The phosphorous, calcium, potassium, iron and magnesium contents of the \\ Received : 15/07/2020 \\ Accepted : 29/11/2020 \\ bread sweetened with date fruit pulp were higher when compared to the bread samples that \\ contained granulated sugar. Bread samples that contained date fruit exhibited greater DPPH radical \\ scavenging activities, metal chelating activities, FRAP and possessed higher inhibition against $\alpha$ - \\ amylase and glucosidase when compared with bead that contained granulated sugar. The results \\ also showed greater antioxidant and enzyme inhibitory activities in the bread sweetened with dry \\ date fruits that the wet date fruits. The sensory results showed that bread sweetened with granulated \\ Keywords: \\ Antioxidant properties \\ Alpha amylase \\ Alpha glucosidase \\ sugar and the date fruits were not significantly different from one another. The overall results \\ showed date fruit has dual potentials in bread, as sweetener and as ingredient in enhancing
} Date fruit

Bread

akinsolaalbert@gmail.com (iD) https://orcid.org/0000-0003-1474-1785

|b@sunkanmig@yahoo.com

D https://orcid.org/0000-0002-9458-7556

This work is licensed under Creative Commons Attribution 4.0 International License

\section{Introduction}

The use of sucrose in bread making is popular because of its sweetening properties and its ability to participate in increasing the volume of loaf of bread. Concerns about the health issues arising from consumption granulated sugar in bread is occupying the research space. The addition of date fruit to bread recipe during baking acted as sweetening agent and also enhanced overall nutritional properties of bread. This study may form a basis for improving the utilization of date fruit as alternative to granulated sugar in bread making.

Date (Thoory Date) is widely cultivated in the Northern region of Nigeria (Hamada et al., 2002). During processing, the kernel is removed and the other parts of the fruit can be consumed (Eong et al., 2006). The fruit of date palm is an ideal source of food that provides numerous essential nutrients of potential health benefits (Marwa, 2018). Dates are consumed in the dried form, as paste, syrup, pickles, jams, jellies, and are used in many bakery or confectionary products together with chocolate, coconut, honey and vinegar (Marwa, 2018). Date fruit is an important source of carbohydrate, containing up-to $70 \%$ with about $29-34 \%$ of glucose, fructose and sucrose contents (Ali et al., 2009; Ismail et al., 2006). Date is a poor source of protein, with less than $2 \%$ protein content but rich in fibre. Drying of date fruits increase the protein and the fibre contents through the loss of moisture (Ishurd et al., 2004). Date fruit is a rich source of phytochemicals such as carotenoids, the phenolics, mainly the cinnamic acids (Shahidi et al., 2004; Al-Farsi and Lee, 2008).

Bread is a baked product that is majorly made from wheat flour. The acceptance of bread as a staple food is increasing in the world today due to its convenience and the technology for its production has been in existence for long (Famuwagun et al., 2016). The consumption of bread is expected to rise in Nigeria in coming years, hence the need to ensure the safety of the products (Anyika, and Uwaegbute, 2005). In addition to wheat flour, yeast, butter, salt, sugar and water are also important ingredients (Badifu et al., 2005). The use of added sugar in bread making is crucial because of its sweetening properties. In addition to this, sucrose (granulated sugar) helps to make the bread soft and tender, by absorbing water and slows down the 
formation of gluten strands. Therefore, adding sugar to the dough can speed up the action of the yeast. Many bread consumers shy away from bread that contained excess sugar due to health risk that is associated with added sugar in food. Increased intake of added sugar has been linked to high risk of obesity, cardiovascular diseases, dental caries, glucose intolerance, diabetic mellitus, hypertension and some behavioral complications such as hyperactivity in children (Johnson and Yon, 2010). According to World Health Organization, the tolerance level of added sugar intake of total energy should be $<10 \%$ (Kenz et al., 2005; WHO, 2003). The utilization of fruits in baked products that require sweet taste is a good strategy to reduce added sugar intake. Dates could be an ideal fruits substitute for added sugar in bread making.

Several works have been published on improving the nutritional quality of bread, such as the protein contents, fibre, mineral and antioxidant properties (Ameh et al., 2013, Bolarinwa et al., 2013; Nwosu et al., 2014). Information on replacing the granulated sugar as an ingredient in bread making, especially using fruit is not common. This work therefore established the potentials of date fruit as ingredient in bread making with associated health benefits.

\section{Materials and Methods}

\section{Preparation of Date Fruit Pulp Flour}

Date fruits were sorted, cleaned with water and air dried at room temperature. The cleaned fruits were divided into two portions: the first portion was chopped into smaller sizes and dried in a vacuum oven (Shell Lab, ILMAC Vacuum oven) at a pressure of 100 mbar for $6 \mathrm{~h}$. Vacuum oven was used during drying to minimize the degradation of the composition. The partially dried fruit was milled using a laboratory blender (Sapphire mixer grinder, 3642964 , India) set at the highest speed and this is referred to as dry date in this study. The second portion was chopped into small sizes and pulped using laboratory mortar and pestle into fine paste and packaged in air-tight container as wet date.

\section{Formulation and Production of Wheat Bread-Date Fruit Dough}

The ingredients used in the baking process is shown in Table 1. The samples were mixed individually to make a total of nine samples. Doughs obtained from the ingredients in Table 1 were kneaded, scaled, cut, molded and properly placed in greased baking pans following the bread making process described by Famuwagun et al. (2016). Proofing was done in the proofing chamber at $40^{\circ} \mathrm{C}$ for $90 \mathrm{~min}$ at relative humidity of $38 \%$. The proofed dough was baked in the oven and the bread samples were allowed to cool to room temperature before packaging for further analysis.

\section{Chemical Composition \\ Moisture content}

Moisture content of the samples was determined by the standard AOAC [2012] official method by drying about 3 $\mathrm{g}\left(\mathrm{W}_{1}\right)$ of the samples in a hot air-oven (Uniscope, SM9053, England) at $105 \pm 1{ }^{\circ} \mathrm{C}$ until constant weight ( $\left.\mathrm{W}_{2}\right)$ is obtained. The sample was removed from the oven, cooled in a desiccator and weighed. This continued until constant weight was obtained (difference of $<0.005 \mathrm{~g}$ ). The result was expressed as percentage of dry matter.

Moisture content $(\%)=\frac{\mathrm{W}_{1}-\mathrm{W}_{2}}{\mathrm{~W}_{1}} \times 100$

$\mathrm{W}_{1}=$ Weight of flour before drying

$\mathrm{W}_{2}=$ Weight of flour after drying

\section{Protein content}

The protein content of the samples was determined using the AOAC (2012) method. Ground sample (0.20 g) was weighed into a Kjeldahl flask. Ten millilitres of concentrated sulphuric acid were added followed by one Kjeltec tablet. The mixture was digested on heating racket to obtain a clear solution. The digestate was cooled, and made up to $75 \mathrm{~mL}$ with distilled water and transferred onto kjeldahl distillation unit followed by the addition of $50 \mathrm{~mL}$ of $40 \%$ sodium hydroxide solution. The mixture was then distilled and the ammonia formed in the mixture is subsequently distilled into $25 \mathrm{ml}, 2 \%$ boric acid solution containing $0.5 \mathrm{~mL}$ of the mixture of $100 \mathrm{~mL}$ of bromocresol green solution (prepared by dissolving 100 $\mathrm{mg}$ of bromocresol green in $100 \mathrm{~mL}$ of methanol) and 70 $\mathrm{mL}$ of methyl red solution (prepared by dissolving $100 \mathrm{mg}$ of methyl red in $100 \mathrm{~mL}$ methanol) as indicators. The distillate collected was titrated with $0.05 \mathrm{M} \mathrm{HCl}$. Blank determination was carried out by excluding the sample from the above procedure

$$
\text { Crude protein }(\%)=\frac{1.401 \times \mathrm{M} \times \mathrm{F}(\mathrm{ml} \text { titrant-ml blank })}{\text { sample weight }}
$$

Where:

$\mathrm{M}$ = Molarity of acid used $=0.05$

$\mathrm{F} \quad=$ Kjeldahl factor $=6.25$

Table 1. Formulation of sweetened bread with date fruit

\begin{tabular}{l|cccccccc}
\hline \multicolumn{1}{c|}{ Mixture } & $\begin{array}{c}\text { Wheat } \\
(\mathrm{g})\end{array}$ & $\begin{array}{c}\text { Sugar } \\
(\mathrm{g})\end{array}$ & $\begin{array}{c}\text { Wet date } \\
(\mathrm{g})\end{array}$ & $\begin{array}{c}\text { Dry date } \\
(\mathrm{g})\end{array}$ & $\begin{array}{c}\text { Yeast } \\
(\mathrm{g})\end{array}$ & $\begin{array}{c}\text { Margarine } \\
(\mathrm{g})\end{array}$ & $\begin{array}{c}\text { Salt } \\
(\mathrm{g})\end{array}$ & $\begin{array}{c}\text { Water } \\
(\mathrm{mL})\end{array}$ \\
\hline Bread+5\% sugar & 100 & 5 & - & - & 1.5 & 5 & 1 & 60 \\
Bread+10\% sugar & 100 & 10 & - & - & 1.5 & 5 & 1 & 60 \\
Bread+15\% sugar & 100 & 15 & - & - & 1.5 & 5 & 1 & 60 \\
Bread+5\% dry date & 100 & - & 5 & - & 1.5 & 5 & 1 & 60 \\
Bread+10\% dry date & 100 & - & 10 & - & 1.5 & 5 & 1 & 60 \\
Bread+15\% dry date & 100 & - & 15 & - & 1.5 & 5 & 1 & 60 \\
Bread+5\% wet date & 100 & - & - & 5 & 1.5 & 5 & 1 & 60 \\
Bread+10\% wet date & 100 & - & - & 10 & 1.5 & 5 & 1 & 60 \\
Bread+15\% wet date & 100 & - & - & 15 & 1.5 & 5 & & 1 \\
\hline
\end{tabular}




\section{Total Ash content}

The total ash content of the samples was determined by the official AOAC (2012) method in a muffle furnace (Carbolite AAF1100, United Kingdom). About $2 \mathrm{~g}\left(\mathrm{~W}_{3}\right)$ of the samples was weighed into a pre-weighed ashing crucible $\left(\mathrm{W}_{2}\right)$ and placed in the muffle furnace chambers at $550^{\circ} \mathrm{C}$ until the samples become ashes usually within $5 \mathrm{~h}$. The crucibles were removed, cooled in a desiccator and weighed $\left(\mathrm{W}_{1}\right)$. Ash content was expressed as the percentage of the weight of the original sample as shown in equation below;

$$
\begin{aligned}
& \text { Ash content }(\%)=\left(\frac{\mathrm{W}_{1}-\mathrm{W}_{2}}{\mathrm{~W}_{3}}\right) \times 100 \\
& \mathrm{~W}_{1}=\text { Weight of crucible+ash } \\
& \mathrm{W}_{2}=\text { Weight of empty crucible } \\
& \mathrm{W}_{3}=\text { Weight of sample }
\end{aligned}
$$

\section{Crude fibre content}

The crude fibre was determined using the AOAC (2012). Two grams $\left(\mathrm{W}_{3}\right)$ of sample was dissolved in 200 $\mathrm{mL}$ of $1.25 \%(\mathrm{v} / \mathrm{v})$ sulphuric acid in a conical flask and was placed on a hot plate and boiled for $30 \mathrm{~min}$. The content was filtered using filter paper (Whatman No.1) and the residue on the filter paper was washed with $70 \mathrm{~mL}$ distilled water. The washed residue was transferred back into the flask and about $200 \mathrm{~mL} 1.25 \%$ (w/v) $\mathrm{NaOH}$ is added and boiled for $30 \mathrm{~min}$. The content was filtered as described earlier and the residue obtained was washed with distilled water and then filtered again using filter paper (Whatman No.1). The residue is then transferred to an ashing dish and dried at $130^{\circ} \mathrm{C}$ for $2 \mathrm{~h}$, cooled in a desiccator and weighed $\left(\mathrm{W}_{1}\right)$. This was then ashed at $550^{\circ} \mathrm{C}$ inside the muffle furnace chamber (Carbolite AAF1100, United Kingdom) for $30 \mathrm{~min}$, cooled and reweighed $\left(\mathrm{W}_{2}\right)$. The ash obtained was subtracted from the residue and the difference expressed as percentage of the starting material as shown in equation below;

$$
\mathrm{Cf}=\left(\frac{\mathrm{W}_{1}-\mathrm{W}_{2}}{\mathrm{~W}_{3}}\right) \times 100
$$

$$
\begin{aligned}
& \text { Where, } \\
& \begin{array}{ll}
\mathrm{Cf} & =\text { Crude fibre }(\%) \\
\mathrm{W}_{1}=\text { Mass of crucible with the dried residue }(\mathrm{g}) & \\
\mathrm{W}_{2}=\text { Mass of crucible with the ash }(\mathrm{g}) \\
\mathrm{W}_{3}=\text { Mass of sample }(\mathrm{g})
\end{array}
\end{aligned}
$$

\section{Crude fat content}

Crude fat was determined by the AOAC (2012) method using soxhlet apparatus (Sunbim, India). About 5 grams $\left(\mathrm{W}_{3}\right)$ of the ground sample was placed into a thimble which was placed inside soxhlet extractor and n-hexane was poured into a pre-weighed round bottom flask $\left(\mathrm{W}_{2}\right)$, used to extract the oil from the sample. The extraction was carried out for about $6 \mathrm{~h}$. The solvent was removed from the extracted oil by distillation. The oil in the flask is further dried in a hot-air oven at $90^{\circ} \mathrm{C}$ for 30 minutes to remove residual organic solvent and moisture. This is cooled in a desiccator and flask and its content weighed
$\left(\mathrm{W}_{1}\right)$. The quantity of oil obtained was expressed as percentage of the original sample used using equation (3) given below:

$$
\text { Ether extract }(\%)=\frac{\mathrm{W}_{1}-\mathrm{W}_{2}}{\mathrm{~W}_{3}} \times 100
$$

$$
\begin{aligned}
& \text { Where, } \\
& \begin{array}{l}
\mathrm{W}_{1}=\text { Weight of flask+oil } \\
\mathrm{W}_{2}=\text { Weight of empty flask } \\
\mathrm{W}_{3}=\text { Weight of sample }
\end{array}
\end{aligned}
$$

\section{Mineral Contents}

Five hundred milligram $(500 \mathrm{mg}$ ) of sample was weighed in a digesting flask and $10 \mathrm{~mL}$ of each of $\mathrm{HCl}$ and $\mathrm{HNO}_{3}$ was added. The mixture was digested for 10 minutes on a Bunsen burner and allowed to cool. The mixture was then filtered using filter paper and the filtrate was made up-to $\mathrm{mL}$ with distilled water and injected into the atomic absorption spectroscopy (Perkin Elmer, model 402) for quantification of the mineral elements except potassium which was determined using flame photometer (Sevindik, 2018).

\section{Antioxidant Properties}

1, 1-diphenylpicrylhydrazine (DPPH) radical scavenging activities

The 1,1-diphenylpicrylhydrazine (DPPH) radical scavenging activity was determined using the method described by Girgih et al. (2011). Five hundred milligram (500 mg) of the sample was in $0.1 \mathrm{M}$ sodium phosphate buffer, $\mathrm{pH}$ 7.0. DPPH was dissolved in $95 \%$ methanol to a final concentration of $100 \mu \mathrm{M}$. A $100 \mu \mathrm{L}$ aliquot of each sample was mixed with $100 \mu \mathrm{L}$ of the DPPH radical solution in a clean test-tube and incubated at room temperature in the dark for $30 \mathrm{~min}$. The buffer was used in the blank assay while reduced ascorbic acid served as the positive control. Absorbance was measured at $517 \mathrm{~nm}$ using a spectrophotometer and the percentage DPPH radical scavenging activity (DPPH-RSA) was determined using the following equation:

$$
\text { DPPH-RSA }(\%)=\frac{(\mathrm{A} 1-\mathrm{A} 2)}{\mathrm{A} 1} \times 100
$$

Where, A1 and A2, are absorbance of the blank and sample, respectively where $A_{b}$ and $A_{s}$, are absorbance of the blank and sample, respectively.

Ferric reducing antioxidant properties (FRAP)

The FRAP was determined using the modified method of Benzie and Strain (1999). FRAP working reagent was prepared by mixing $300 \mathrm{mM}$ acetate buffer of $\mathrm{pH} 3.6,10$ $\mathrm{mM}$ 2,4,6-tri-(2-pyridyl)-1,3,5-triazine, and $20 \mathrm{mM} \mathrm{FeCl}_{3}$ in the ratio of $5: 1: 1$, respectively to obtain a straw-colored solution, and the temperature of the mixture raised to $37^{\circ} \mathrm{C}$. Five hundred milligram of the sample was dissolved in distilled water. Into a clear test-tube, $200 \mu \mathrm{L}$ of samples and $1000 \mu \mathrm{L}$ of FRAP reagent was added and absorbance read at $593 \mathrm{~nm}$. Iron II sulfate heptahydrate $\left(\mathrm{FeSO}_{4} \cdot 7 \mathrm{H}_{2} \mathrm{O}\right)$ at $0.025-0.25 \mathrm{mM}$ was used as standard. Iron reducing activity of the samples was determined from the standard curve and the results expressed as $\mathrm{Fe}^{2+}(\mathrm{mM})$. 


\section{Metal chelation ability}

The metal (iron) chelating ability (MCA) of the samples was determined according to the modified method of Xie et al. (2008). Five hundred milligram of the sample was dissolved in distilled water. A $1 \mathrm{~mL}$ aliquot of the sample solution or blank (distilled water) was mixed with $50 \mu \mathrm{L}$ of $2 \mathrm{mM} \mathrm{FeCl}_{2}$ and $1.85 \mathrm{~mL}$ double distilled water in a reaction tube. This was followed by the addition of 100 $\mu \mathrm{L}$ of $5 \mathrm{mM}$ Ferrozine. The mixture was vortexed thoroughly and incubated at room temperature for $10 \mathrm{~min}$ and absorbance values of both the blank $(\mathrm{Ab})$ and samples (As) were measured at $562 \mathrm{~nm}$ using spectrophotometer. The metal chelating activity (MCA) was calculated as follows;

$$
\operatorname{MCA}(\%)=\frac{(\mathrm{Ab}-\mathrm{As})}{\mathrm{Ab}} \times 100
$$

Where, $\mathrm{Ab}$ is the absorbance of the blank and As is the sample absorbance.

\section{Determination of Total Phenolic Content}

The total phenolic content (TPC) was determined following the method described by Gulcin et al. (2003) using the Folin Ciocalteu's phenol reagent which is an oxidizing reagent. A 10-fold dilution of Folin-Ciocalteu reagent was prepared just prior to use. Five hundred milligram of the sample was hydrated in $5 \mathrm{~mL}$ distilled water and centrifuged. To $100 \mu \mathrm{L}$ of the sample supernatant was added $900 \mu \mathrm{L}$ of distilled water to give 10 folds dilution. Two hundred microliters $(200 \mu \mathrm{L})$ of freshly prepared diluted Folin-Ciocalteu's phenol reagent was added and the mixture was vortexed. After allowing the mixture to equilibrate for $5 \mathrm{~min}$, the reaction was then neutralized with $1.0 \mathrm{~mL}$ of $7 \%$ (w/v) $\mathrm{Na}_{2} \mathrm{CO}_{3}$ solution. After $2 \mathrm{~h}$ of incubation at room temperature, the absorbance was measured at $750 \mathrm{~nm}$. A standard curve was prepared with a linear range of $0.0-0.1 \mathrm{mg} / \mathrm{mL}$ using Gallic acid. The results were expressed as milligram Gallic acid equivalent ( $\mu \mathrm{g}$ GAE/ $\mathrm{ml}$ ) of juice and this was obtained by extrapolation from the standard curve. Distilled water was used as blank.

\section{Enzyme Inhibitory Properties of the Bread Samples} Inhibition of $\alpha$-amylase enzyme activity

Inhibition of porcine $\alpha$-amylase activity was determined using the dinitrosalicylic acid described by Kwon et al. (2006). One gram (1 g) of the sample was hydrated in in $0.02 \mathrm{M}$ phosphate buffer, $\mathrm{pH} 6.9$ containing $0.006 \mathrm{M} \mathrm{NaCl}$. One hundred microlitres $(100 \mu \mathrm{L})$ of the sample was added to $100 \mu \mathrm{L}$ of $\alpha$-amylase $(1 \mathrm{mg} / \mathrm{mL}$ final concentration in $0.02 \mathrm{M}$ phosphate buffer, $\mathrm{pH} 6.9$ containing $0.006 \mathrm{M} \mathrm{NaCl}$ ). The mixtures were preincubated at $28^{\circ} \mathrm{C}$ for 10 minutes and $200 \mu \mathrm{L}$ of $1 \%$ starch (prepared in $0.02 \mathrm{M}$ phosphate buffer, $\mathrm{pH} 6.9$ containing $0.006 \mathrm{M} \mathrm{NaCl}$ ) was added. The reaction mixtures were incubated at room temperature for 10 minutes. The reactions were stopped by incubating the mixture in a boiling water bath for 5 minutes after adding $1 \mathrm{~mL}$ of dinitrosalicylic acid. The reaction mixtures were cooled to room temperature, diluted to 1:5 ratio with distilled water and the absorbance was measured in a at $540 \mathrm{~nm}$ using spectrophotometer. The percentage inhibition of enzyme activity was calculated as;

$$
\mathrm{AAI}=\frac{(\mathrm{AC}-(\mathrm{AS}-\mathrm{ASB}))}{\text { Absorbance of control }} \times 100
$$

$\mathrm{AAI}=$ Alpha-amylase inhibition

$\mathrm{AC}=$ Absorbance of control

AS = Absorbance of sample

$\mathrm{ASB}=$ Absorbance of sample blank

\section{Inhibition of A-Glucosidase Enzyme}

Inhibition of $\alpha$-glucosidase activity was determined using yeast $\alpha$-glucosidase and p-nitrophenyl- $\alpha$-Dglucopyranoside (pNPG) as described by Kim et al. (2004). One hundred microlitres $(100 \mu \mathrm{L})$ of hydrated sample or standard (acarbose; $0.25 \mathrm{mg} / \mathrm{mL}$ final concentrations dissolved in 0.1 M phosphate buffer, $\mathrm{pH}$ 6.9) was added to $50 \mu \mathrm{L}$ of $\alpha$-glucosidase $(1 \mathrm{mg} / \mathrm{mL}$ final concentration in 0.1 $\mathrm{M}$ phosphate buffer). The mixtures were pre-incubated at $37^{\circ} \mathrm{C}$ for 20 minutes. After pre-incubation, $100 \mu \mathrm{L}$ of $5 \mathrm{mM}$ pNPG (dissolved in 0.1 M phosphate buffer, pH 6.9) was added and incubated at $37^{\circ} \mathrm{C}$ for $10 \mathrm{~min}$ and the absorbance was read at $405 \mathrm{~nm}$ using spectrophotometer. Percentage of inhibition of the enzyme activity was calculated as;

$$
\alpha-\mathrm{GI}=\frac{(\mathrm{FAB}-(\mathrm{FAS})}{\mathrm{FAB}} \times 100
$$

GI = Glucosidase inhibition

$\mathrm{FAB}=$ Final absorbance of blank

FAS $=$ Final absorbance of sample

\section{Sensory Evaluation}

The bread samples were subjected to sensory analysis using 9-hedonic scale. A total of twenty panelists were served with coded bread samples in clean white plates at room temperature. The panelists were asked to evaluate products and score each sample using a 9-using the scale where 1 = extremely unacceptable and $9=$ extremely acceptable. Sensory attributes evaluated include: bread appearance, crust color, crumb color, texture, taste, chew ability, flavor and overall acceptability.

\section{Statistical Analysis}

Data obtained from the work was subjected to analysis of variance (ANOVA) and means was separated using Duncan multiple range test. Significance differences among the samples were selected at $\mathrm{P}<0.05$.

\section{Results and Discussion}

\section{Proximate Composition}

The proximate composition bread sweetened with date fruit and granulated sugar is shown in Table 2. Vacuum oven drying reduced the moisture content of date fruit $28.43 \%$ to $12.23 \%$. The moisture content of the bread samples ranged between 14.63 to $15.82 \%$. There was no significant $(\mathrm{P}>0.05)$ difference in the moisture contents of the bread samples. The results suggest neither wet date nor dry date affected the moisture content of the bread samples. Fat was not detected in the dry and the fresh date fruit. 
Table 2. Proximate composition of bread sweetened with date fruit

\begin{tabular}{l|ccccc}
\hline \multicolumn{1}{c|}{ Mixture } & $\begin{array}{c}\text { Moisture } \\
(\%)\end{array}$ & $\begin{array}{c}\text { Crude fat } \\
(\%)\end{array}$ & $\begin{array}{c}\text { Ash } \\
(\%)\end{array}$ & $\begin{array}{c}\text { Fibre } \\
(\%)\end{array}$ & $\begin{array}{c}\text { Crude Protein } \\
(\%)\end{array}$ \\
\hline Wet date fruit & $28.43 \pm 0.04^{\mathrm{a}}$ & n.d. & $0.85 \pm 0.06^{\mathrm{a}}$ & $1.54 \pm 0.09^{\mathrm{b}}$ & $1.21 \pm 0.22^{\mathrm{e}}$ \\
Dry date fruit & $12.23 \pm 3.34^{\mathrm{c}}$ & n.d. & $0.78 \pm 0.28^{\mathrm{c}}$ & $3.89 \pm 0.01^{\mathrm{a}}$ & $4.24 \pm 0.07^{\mathrm{d}}$ \\
Bread+5\% sugar & $15.23 \pm 3.34^{\mathrm{b}}$ & $0.22 \pm 0.02^{\mathrm{a}}$ & $0.53 \pm 0.00^{\mathrm{e}}$ & $0.36 \pm 0.02^{\mathrm{f}}$ & $9.60 \pm 0.05^{\mathrm{c}}$ \\
Bread+10\% sugar & $15.34 \pm 0.35^{\mathrm{b}}$ & $0.22 \pm 0.02^{\mathrm{a}}$ & $0.53 \pm 0.01^{\mathrm{e}}$ & $0.36 \pm 0.02^{\mathrm{f}}$ & $9.60 \pm 0.05^{\mathrm{c}}$ \\
Bread+15\% sugar & $15.03 \pm 0.15^{\mathrm{b}}$ & $0.23 \pm 0.01^{\mathrm{a}}$ & $0.53 \pm 0.01^{\mathrm{e}}$ & $0.36 \pm 0.02^{\mathrm{f}}$ & $9.60 \pm 0.05^{\mathrm{c}}$ \\
Bread+5\% dry date & $14.63 \pm 0.35^{\mathrm{b}}$ & $0.25 \pm 0.01^{\mathrm{a}}$ & $0.62 \pm 0.02^{\mathrm{d}}$ & $1.04 \pm 0.11^{\mathrm{d}}$ & $9.76 \pm 0.02^{\mathrm{b}}$ \\
Bread+10\% dry date & $15.73 \pm 0.40^{\mathrm{b}}$ & $0.22 \pm 0.02^{\mathrm{a}}$ & $0.67 \pm 0.02^{\mathrm{c}}$ & $1.08 \pm 0.06^{\mathrm{c}}$ & $9.88 \pm 0.02^{\mathrm{a}}$ \\
Bread+15\% dry date & $15.40 \pm 0.30^{\mathrm{b}}$ & $0.22 \pm 0.01^{\mathrm{a}}$ & $0.74 \pm 0.04^{\mathrm{b}}$ & $1.11 \pm 0.10^{\mathrm{c}}$ & $9.92 \pm 0.01^{\mathrm{a}}$ \\
Bread+5\% wet date & $15.42 \pm 0.54^{\mathrm{b}}$ & $0.22 \pm 0.02^{\mathrm{a}}$ & $0.70 \pm 0.04^{\mathrm{bc}}$ & $0.65 \pm 0.05^{\mathrm{e}}$ & $9.69 \pm 0.84^{\mathrm{b}}$ \\
Bread+10\% wet date & $15.82 \pm 0.73^{\mathrm{b}}$ & $0.23 \pm 0.06^{\mathrm{a}}$ & $0.74 \pm 0.08^{\mathrm{b}}$ & $0.69 \pm 0.08^{\mathrm{e}}$ & $9.69 \pm 0.82^{\mathrm{b}}$ \\
Bread+15\% wet date & $15.34 \pm 0.44^{\mathrm{b}}$ & $0.25 \pm 0.05^{\mathrm{a}}$ & $0.78 \pm 0.09^{\mathrm{ab}}$ & $0.79 \pm 0.04^{\mathrm{e}}$ & $9.86 \pm 0.32^{\mathrm{a}}$ \\
\hline
\end{tabular}

Values are mean \pm s.d. of triplicate determinations. Values with superscript along the same coloum are significantly $(\mathrm{P}<0.05)$ different from one another

However, the fat content of the bread samples ranged between 0.22 to $0.25 \%$, as shown in Table 2. No significant $(\mathrm{P}>0.05)$ difference was observed in the fat contents. The lipid observed in the bread samples may be due to the presence of margarine in the bread recipe.

The ash is an indication of mineral elements in food. The ash content of the bread samples ranged between 0.53 and $0.78 \%$. Drying decreased the ash content of the date fruit from $0.85 \%$ to $0.68 \%$. There was no significant $(\mathrm{P}>0.05)$ difference in the ash content of bread samples sweetened with granulated sugars, irrespective of the proportion added $(5-15 \%)$. The ash content of bread sweetened with dry date ranged between 0.62 and $0.74 \%$, and those sweetened with wet date were between 0.70 and $0.78 \%$. The values increased as the proportion of the date fruit in the bread increased. The ash content of bread sweetened with date fruit were significantly $(\mathrm{P}<0.05)$ higher when compared with the values reported for bread sweetened with granulated sugar. Odunlade et al. (2017) and Pragati et al. (2017) had earlier reported 1.10 to $2.40 \%$ and 1.06 to $1.98 \%$ for the ash content of bread supplemented with edible vegetable leaves and bread enriched with grass powder respectively. The differences in values may be attributable to the variation in the source of plant materials (date vs vegetables) and (fruit vs leaves).

Vacuum drying improved the fibre content of the date fruit from 1.54 to $3.89 \%$ and this may be attributable to the removal of water during drying. This observation is supported by the findings of Ishurd et al. (2004) that removal of water from date fruit increased the fibre contents of the fruit. The fibre content of bread sweetened with date fruit $(0.65-1.11 \%)$ were significantly higher $(\mathrm{P}<0.05)$ when compared with the fibre content of bread sweetened with granulated sugar $(0.36 \%)$. No significant $(\mathrm{P}>0.05)$ difference was observed in the fibre content by varying the level of granulated sugar in the bread. This may be explained on the basis of single compound nature of granulated sugar. The granulated sugar is made of pure sucrose, and no interaction with other compounds that cause increase or decrease in the composition. In contrast, increase in the level of addition of date fruit in bread enhanced the fibre contents, this suggest interaction with other compounds withing the date fruit. Bread enriched with wet date fruit had significantly lower fibre content $(0.65-0.79 \%)$ when compared with bread sweetened with the fibre content (1.04-1.11\%) of bread sweetened with dry date. The high fibre content of dry date may be attributed to this pattern. Food material rich in dietary fibre has implication in reducing the incidence of various diseases such as obesity and other cardiovascular diseases (Anderson et al., 2009).

Vacuum drying enhanced the protein content of the date fruit and increased the value from 1.54 to $4.24 \%$. This may suggest protein concentration due to removal of water from the date. Earlier report by Ishurd et al. (2006) reported increase in the protein content of date as a result of removal of water. The protein content of bread sweetened with granulated sugar was $9.60 \%$, which was significantly $(\mathrm{P}<0.05)$ lower when compared with bread sweetened with date fruit $(9.69-9.92 \%)$. Interestingly, the results showed that addition of date fruit contributed to the protein content of bread, which is important in boasting the protein energy malnutrition of bread. However, bread sweetened with dry date $(9.76-9.92 \%)$ had higher protein content when compared with bread sweetened with wet date fruit (9.69$9.86 \%$ ) and this may be attribute to the higher protein content in dry date. This observation was in line with previous works by Odunlade et al. (2017), Pargati et al. (2017) and Anderson et al. (2009) where the protein content of bread enriched with leafy vegetable, wheat grass powder and achia flour respectively were enhanced. The overall results of the proximal composition showed that the use of date fruit contributed to the basic nutrient of bread, in addition to its roles as sweetening agents unlike the use of granulated sugar.

\section{Mineral Composition}

The mineral content date fruit and bread sweetened with date fruit and granulated sugar is shown in Table 3. Vacuum drying process improved the phosphorous content of date fruit from 52.90 to $64.88 \mathrm{mg} / 100 \mathrm{~g}$. The phosphorous content of bread sweetened with granulated sugar $(14.90-14.94 \mathrm{mg} / 100 \mathrm{~g})$ were significantly $(\mathrm{P}<0.05)$ lower, when compared to the phosphorous content of bread sweetened with dry date $(19.0-45.10 \mathrm{mg} / 100 \mathrm{~g})$ and wet date (14.99-39.34 mg/100 g). The phosphorous content of the bread samples increased as the level of inclusion of date fruit increased. Similarly, bread sweetened with dry date had higher amounts of phosphorous, when compared with the wet date. As shown in Table 3, bread sweetened with granulated sugar contained $5.35-5.36 \mathrm{mg} / 100 \mathrm{~g}, 2.15-2.16$ $\mathrm{mg} / 100 \mathrm{~g}, 146.62-146.80 \mathrm{mg} / 100$ and $249.50-249.87$ $\mathrm{mg} / 100 \mathrm{~g}$ for potassium, iron, magnesium and calcium contents respectively. These values were lower when 
compared with values (269.20-288.60 mg/100 g, 5.34-5.39 $\mathrm{mg} / 100 \mathrm{~g}, 2.18-2.20 \mathrm{mg} / 100 \mathrm{~g}$ and $146.65-146.98 \mathrm{mg} / 100$ g) obtained for bread sweetened with date fruit. There was no significant $(\mathrm{P}>0.05)$ increase in the mineral contents of the bread samples as the level of incorporation of the date fruit increased and this may suggest that addition of high amounts of date fruit did not contribute to the mineral contents of the bread samples. Bread sweetened with dry date contained higher mineral contents when compared to bread samples that were sweetened with wet date. This pattern may be attributable to mineral concentration, through the removal of water from the dry date fruit by the vacuum drying process. Previous work by Odunlade et al. (2017) reported increase in the mineral contents of bread samples when leafy vegetable powder was supplemented in wheat bread.

Table 3. Mineral composition of bread sweetened with date fruit

\begin{tabular}{l|ccccc}
\hline \multicolumn{1}{c|}{ Mixture } & $\begin{array}{c}\text { Phosphorous } \\
(\mathrm{mg} / 100 \mathrm{~g})\end{array}$ & $\begin{array}{c}\text { Calcium } \\
(\mathrm{mg} / 100 \mathrm{~g})\end{array}$ & $\begin{array}{c}\text { Potassium } \\
(\mathrm{mg} / 100 \mathrm{~g})\end{array}$ & $\begin{array}{c}\text { Iron } \\
(\mathrm{mg} / 100 \mathrm{~g})\end{array}$ & $\begin{array}{c}\text { Magnesium } \\
(\mathrm{mg} / 100 \mathrm{~g})\end{array}$ \\
\hline Wet date fruit & $52.90 \pm 0.26^{\mathrm{b}}$ & $100.30 \pm 0.31^{\mathrm{f}}$ & n.d. & $0.85 \pm 0.00^{\mathrm{c}}$ & $0.54 \pm 0.01^{\mathrm{e}}$ \\
Dry date fruit & $64.88 \pm 2.50^{\mathrm{a}}$ & $61.77 \pm 0.20^{\mathrm{g}}$ & $1.04 \pm 0.03^{\mathrm{b}}$ & $0.90 \pm 0.04^{\mathrm{b}}$ & $1.37 \pm 0.03^{\mathrm{d}}$ \\
Bread+5\% sugar & $14.90 \pm 0.06^{\mathrm{h}}$ & $249.50 \pm 0.06^{\mathrm{e}}$ & $5.35 \pm 0.02^{\mathrm{a}}$ & $2.15 \pm 0.10^{\mathrm{a}}$ & $146.62 \pm 0.28^{\mathrm{c}}$ \\
Bread+10\% sugar & $14.91 \pm 0.07^{\mathrm{i}}$ & $249.80 \pm 0.55^{\mathrm{e}}$ & $5.36 \pm 0.19^{\mathrm{a}}$ & $2.16 \pm 0.12^{\mathrm{a}}$ & $146.77 \pm 0.32^{\mathrm{c}}$ \\
Bread+15\% sugar & $14.94 \pm 0.06^{\mathrm{i}}$ & $249.87 \pm 0.11^{\mathrm{e}}$ & $5.36 \pm 0.28^{\mathrm{a}}$ & $2.15 \pm 0.17^{\mathrm{a}}$ & $146.80 \pm 0.30^{\mathrm{bc}}$ \\
Bread+5\% dry date & $19.70 \pm 0.39^{\mathrm{g}}$ & $269.20 \pm 1.14^{\mathrm{d}}$ & $5.37 \pm 0.12^{\mathrm{a}}$ & $2.18 \pm 0.03^{\mathrm{a}}$ & $146.90 \pm 0.21^{\mathrm{b}}$ \\
Bread+10\% dry date & $35.10 \pm 0.25^{\mathrm{e}}$ & $279.90 \pm 0.05^{\mathrm{c}}$ & $5.39 \pm 0.03^{\mathrm{a}}$ & $2.19 \pm 0.02^{\mathrm{a}}$ & $146.96 \pm 0.59^{\mathrm{a}}$ \\
Bread+15\% dry date & $45.10 \pm 0.02^{\mathrm{c}}$ & $286.60 \pm 5.04^{\mathrm{b}}$ & $5.39 \pm 0.13^{\mathrm{a}}$ & $2.20 \pm 0.03^{\mathrm{a}}$ & $146.98 \pm 0.61^{\mathrm{a}}$ \\
Bread+5\% wet date & $14.99 \pm 0.11^{\mathrm{h}}$ & $286.90 \pm 1.71^{\mathrm{a}}$ & $5.34 \pm 0.02^{\mathrm{a}}$ & $2.18 \pm 0.30^{\mathrm{a}}$ & $146.65 \pm 1.01^{\mathrm{c}}$ \\
Bread+10\% wet date & $25.00 \pm 0.10^{\mathrm{f}}$ & $287.90 \pm 1.71^{\mathrm{a}}$ & $5.34 \pm 0.01^{\mathrm{a}}$ & $2.18 \pm 0.11^{\mathrm{a}}$ & $146.67 \pm 1.70^{\mathrm{c}}$ \\
Bread+15\% wet date & $39.34 \pm 0.55^{\mathrm{d}}$ & $288.60 \pm 1.73^{\mathrm{a}}$ & $5.35 \pm 0.01^{\mathrm{a}}$ & $2.19 \pm 0.10^{\mathrm{a}}$ & $146.67 \pm 0.60^{\mathrm{c}}$ \\
\hline Values are mean \pm s.d. of triplicate determinations. Values with superscript along the same column are significantly $(\mathrm{P}<0.05)$ different from one another
\end{tabular}
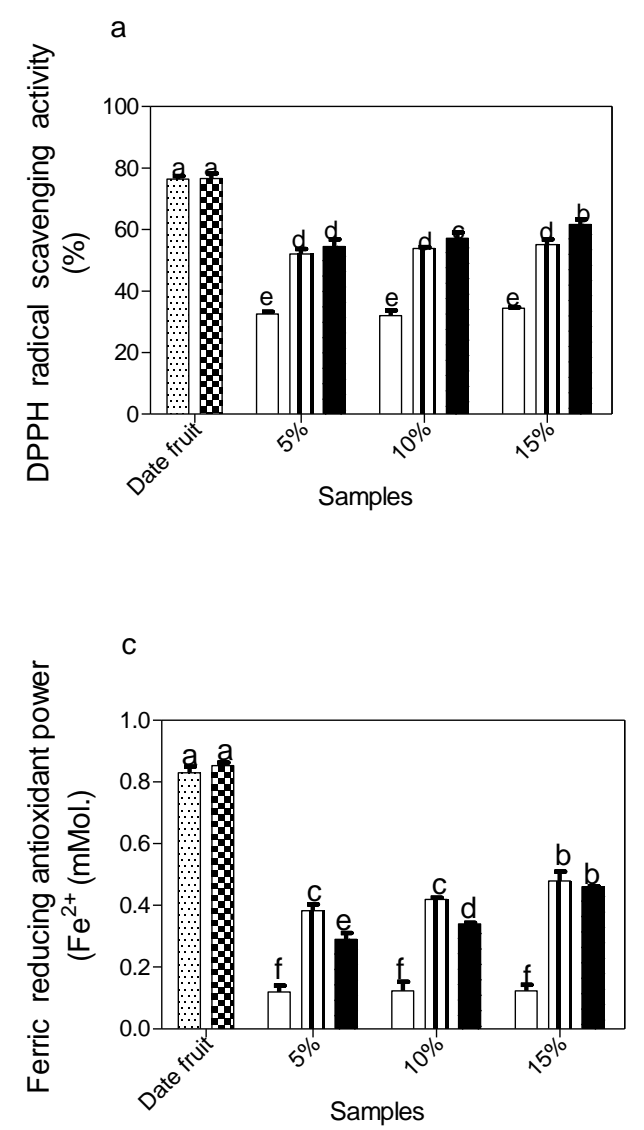

b

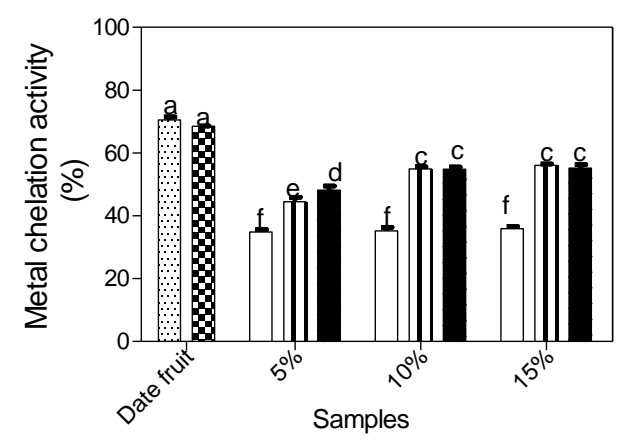

d

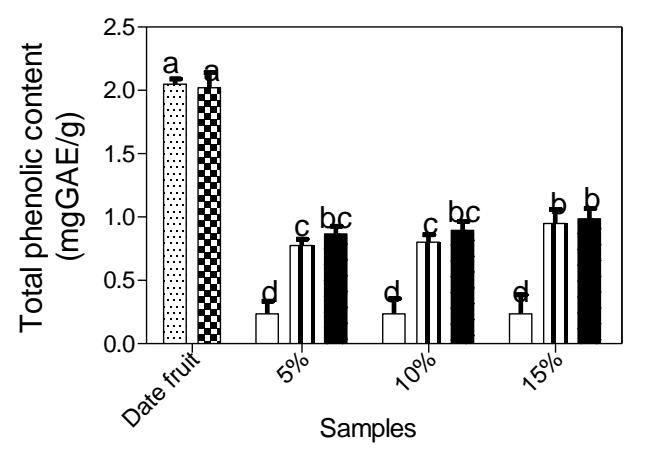

\footnotetext{
5 Date fruit $\mathbf{8}$ bread+granulated sugar

Wu bread+wet date

bread + wet date
}

Figure 1. Effects of date fruits and granulated sugar addition on

(a) DPPH radical scavenging, activities (b) Metal chelating activities (c) Ferric reducing antioxidant property (d) Total phenolic content of wheat bread 


\section{Antioxidant Properties}

DPPH radical scavenging, metal chelating activities and ferric reducing antioxidant power were the antioxidant properties used in evaluating the potentials of the samples to act as antioxidant agents.

The DPPH assays were used to indicate the direct activities of the samples as primary antioxidant and the results for bread sweetened with date fruit and granulated sugar is shown in Figure 1a. There was no significant $(\mathrm{P}>0.05)$ difference in the DPPH radical scavenging ability of wet date (76.44\%) dry date (76.59\%), and this suggests that drying the date fruit did not have significant effect on the DPPH radical scavenging activities of the date fruit. The DPPH radical scavenging activities of the bread samples ranged between 32.05 to $61.63 \%$. Bread sweetened with wet date had greater DPPH radical scavenging ability when compared with bread sweetened with dry date fruit. Bread sweetened with date fruit had stronger DPPH radical scavenging activities than bread sweetened with granulated sugar. Previous studies 33.61 to $68.54 \%$ and 54.97 to $87.84 \%$ for bread enriched with raw mango peel (Pathak et al., 2017) and edible leafy vegetable (Odunlade et al., 2017). The metal chelating assay was used as an indirect method to measure the activities of the juice samples as secondary antioxidant through the binding of the ferrous (Fe II) ion that catalyzes oxidation and subsequently prevents the formation of the $\mathrm{Fe}$ (II)-ferrozine complex (Sulaiman and Ooi, 2014). The chelating ability of bread sweetened with date fruit and granulated sugar is shown in Figure $1 \mathrm{~b}$. The wet date had stronger chelating ability $(70.58 \%)$ than the dry date $(68.58 \%)$, suggesting the vacuum drying reduced the chelating ability of the date fruit. Bread sweetened with granulated sugar had significantly $(\mathrm{P}<0.05)$ lower metal chelating ability when compared with values reported for bread sweetened with date fruit. This may suggest that the added date fruit chelated transition metals better than the granulated sugar, resulting in higher chelating activities (Xie et al., 2008; Sulaiman and Ooi, 2014). There was no significant $(\mathrm{P}>0.05)$ difference in the chelating ability of bread sweetened with 10 and $15 \%$ sweet and dry date fruits. Significant $(\mathrm{P}<0.05)$ difference existed in the chelating activities of bread sweetened with $5 \%$ wet and dry date fruits.

There was no significant $(P>0.05)$ difference in the FRAP content of wet and dry date. The FRAP content of the bread samples ranged between 0.12 to $0.48 \mathrm{mMol} \mathrm{Fe}^{2+}$. The values were low, when compared to 476.16 to 2232.13 $\mathrm{mMol}$ reported for bread enriched with raw mango peel (Pathak et al., 2017). Bread sweetened date fruit had stronger reducing ability than bread sweetened with granulated sugar, and this suggest stronger proton donating ability of the bread samples that contained date fruit (Wang et al., 2008). Bread samples sweetened with dry date fruit exhibited stronger ion reducing ability than those sweetened with wet date, and this may suggest concentration and eventual enhancement of the reducing compound in the added date fruit. There was increase in the reducing ability of the bread sweetened with date fruit, suggesting positive effects in the synergistic ability of the date fruits in the bread and this agreed with the trend reported for bread enriched with leafy vegetable power (Odunlade et al., 2017).

\section{Total Phenolic Content (TPC)}

As shown in Figure 1d, there was no significant $(\mathrm{P}>0.05)$ difference in the phenolic content of dry and wet date samples and this suggested drying did not impact negatively on the phenolic content of the date fruit. Earlier work reported higher phenolic content for dry date fruit when compared with fresh date fruit (Al-Farsi and Lee, 2008). The differences in pattern of phenolic content may be related to varied drying process (i.e., vacuum and oven). The differences in pattern of phenolic content may be related to varied drying process i.e., (vacuum and oven). The phenolic content of the bread samples ranged between 23.6 to $98.6 \mathrm{mg} \mathrm{GAE} / 100 \mathrm{~g}$. The values were lower compared to 223.45 to $794.32 \mathrm{mg} \mathrm{GAE} / 100 \mathrm{~g}$ reported for bread samples enriched with fresh mango peel (Pathak et al., 2017). Bread enriched with date fruit had higher phenolic content, compared with the bread enriched with granulated sugar, and this may be related to the phenolic content of the date fruit. Also, bread sweetened with wet date had higher phenolic content when compared to bread that contained dry date. Vayalil (2002), Guo et al. (2003) and Al-Farsi and Lee (2008) reported that date fruits contained several phenolic compounds such as the protocatechuic acid, caffeic acid, p-coumaric acid, ferulic acid and o-coumaric acid. The presence of these compounds in the date fruits that contained these extra phenolic compounds may be responsible for the high phenolic in breads that were sweetened with date fruits.

a

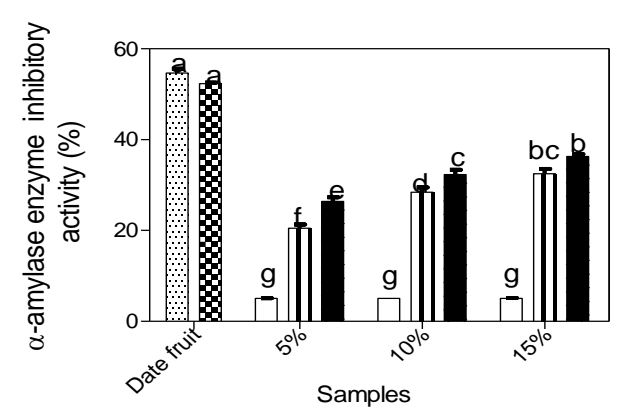

b

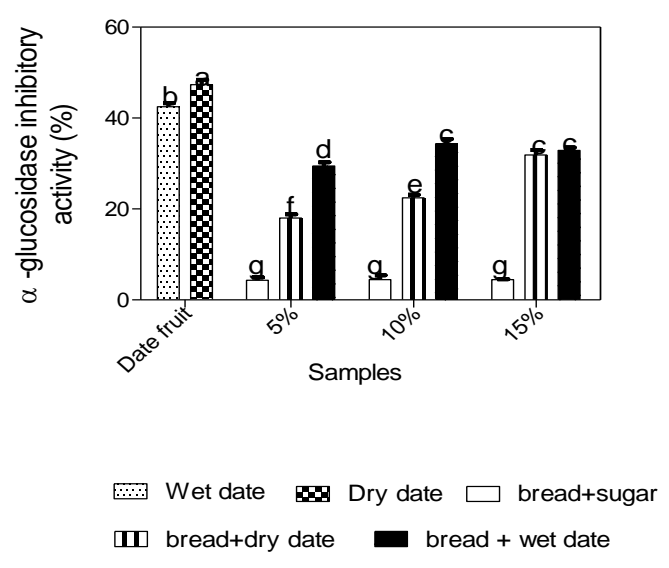

Figure 2. Effects of date fruit and granulated sugar addition on

(a) $\alpha$-Amylase (b) $\alpha$-Glucosidase inhibitory activities of bread samples 
Table 4. Sensory properties of bread sweetened with date fruit

\begin{tabular}{l|ccccc}
\hline \multicolumn{1}{c|}{ Mixture } & Appearance & Texture & Taste & Crust colour & $\begin{array}{c}\text { Overall } \\
\text { acceptability }\end{array}$ \\
\hline Bread+5\% sugar & $8.20 \pm 0.63^{\mathrm{a}}$ & $8.10 \pm 1.66^{\mathrm{b}}$ & $8.10 \pm 0.57^{\mathrm{a}}$ & $7.70 \pm 0.57^{\mathrm{bc}}$ & $8.40 \pm 1.03^{\mathrm{a}}$ \\
Bread+10\% sugar & $8.30 \pm 1.83^{\mathrm{a}}$ & $8.30 \pm 0.82^{\mathrm{a}}$ & $8.30 \pm 0.95^{\mathrm{a}}$ & $7.80 \pm 0.74^{\mathrm{b}}$ & $8.60 \pm 1.16^{\mathrm{a}}$ \\
Bread+15\% sugar & $8.00 \pm 0.94^{\mathrm{a}}$ & $8.60 \pm 0.84^{\mathrm{a}}$ & $8.20 \pm 0.79^{\mathrm{a}}$ & $8.00 \pm 1.05^{\mathrm{a}}$ & $8.80 \pm 1.08^{\mathrm{a}}$ \\
Bread+5\% dry date & $7.00 \pm 1.69^{\mathrm{b}}$ & $8.20 \pm 1.90^{\mathrm{b}}$ & $8.20 \pm 0.92^{\mathrm{a}}$ & $7.20 \pm 1.14^{\mathrm{d}}$ & $8.30 \pm 0.94^{\mathrm{a}}$ \\
Bread+10\% dry date & $6.90 \pm 1.14^{\mathrm{c}}$ & $8.30 \pm 0.88^{\mathrm{c}}$ & $8.60 \pm 0.70^{\mathrm{a}}$ & $7.20 \pm 1.03^{\mathrm{d}}$ & $8.60 \pm 0.79^{\mathrm{a}}$ \\
Bread+15\% dry date & $6.70 \pm 1.37^{\mathrm{d}}$ & $8.40 \pm 0.97^{\mathrm{a}}$ & $8.90 \pm 1.20^{\mathrm{a}}$ & $7.60 \pm 1.27^{\mathrm{c}}$ & $8.70 \pm 1.23^{\mathrm{a}}$ \\
Bread+5\% wet date & $7.20 \pm 1.03^{\mathrm{b}}$ & $8.00 \pm 0.74^{\mathrm{c}}$ & $7.90 \pm 1.07^{\mathrm{a}}$ & $7.30 \pm 1.06^{\mathrm{d}}$ & $8.70 \pm 1.07^{\mathrm{a}}$ \\
Bread+10\% wet date & $7.10 \pm 1.77^{\mathrm{b}}$ & $8.30 \pm 1.93^{\mathrm{a}}$ & $8.50 \pm 2.12^{\mathrm{a}}$ & $7.50 \pm 1.43^{\mathrm{c}}$ & $8.80 \pm 1.34^{\mathrm{a}}$ \\
Bread+15\% wet date & $6.90 \pm 1.66^{\mathrm{c}}$ & $8.60 \pm 1.58^{\mathrm{a}}$ & $8.40 \pm 1.51^{\mathrm{a}}$ & $7.60 \pm 1.16^{\mathrm{bc}}$ & $8.80 \pm 1.03^{\mathrm{a}}$ \\
\hline
\end{tabular}

Values are mean \pm s.d. of triplicate determinations. Values with superscript along the same coloum are significantly (P<0.05) different from one another

\section{Alpha Amylase and Glucosidase Inhibition}

Alpha amylase and glucosidase enzymes are major digestive systems in the body and are responsible in the hydrolysis of starch to glucose and allows the absorption of glucose in the blood streams leading to a rise in the blood glucose levels. Inhibiting these enzymes is one of the best ways to maintain low blood glucose levels and hence, limiting the incidence of diabetics (Guo et al., 2003). Wet date fruit had $54.65 \%$ alpha amylase inhibitory activity, which was higher than $52.34 \%$ obtained for dried date sample as shown in Figure 2a. The results indicated that drying reduced the $\alpha$ - inhibitory activities of the date fruit. The $\alpha$-amylase inhibitory activity of the bread samples ranged between 5.08 to $36.32 \%$. There was no significant $(\mathrm{P}>0.05)$ difference in the $\alpha$-amylase inhibitory activity of bread samples sweetened with granulated sugar, regardless of the level of inclusion in the recipe. Bread sweetened with date fruits had higher $\alpha$-amylase inhibitory activities than bread sweetened with granulated sugar. This observation may be attributable to high phenolic and antioxidant properties of date fruit. Bread sweetened with wet date had stronger alpha amylase inhibitory properties when compared with those sweetened with dry date. The results also showed greater inhibitory activities of amylase enzyme in the bread samples as the level of inclusion of date fruit increased, which suggest greater contribution of inhibitory activities as the amount of date fruit increased in the bread samples.

Similarly, wet date had $42.45 \% \quad \alpha$-glucosidase inhibitory activity and this was significantly $(\mathrm{P}<0.05)$ lower than the $47.32 \%$ observed in dry date. The results indicated that removal of water through drying improved the $\alpha$-glucosidase inhibitory activity of the date fruit. This pattern of results was similar to the observation of Ishurd et al. (2014) that removal of water from date fruit improved alpha glucosidase inhibitory activities. The $\alpha$-glucosidase activities of bread samples 4.32 to $34.33 \%$ (Figure $2 b$ ). The inhibitory activities bread sweetened with granulated sugar was lower when compared with those sweetened with date fruit. The composition of various phenolics on the date fruit may be responsible for the greater alpha glucosidase inhibitory activities of bread sweetened with date fruit.

\section{Sensory Properties}

To attain good eating quality of bread, it is important that sensory features such as appearance, texture, taste, crust and crumb colour, chew ability and overall acceptability be examined and the results is shown in Table
4. The scores for the appearance of the bread samples ranged between 6.90 to 8.30. Bread samples sweetened with granulated sugar had high preference when compared with the bread that were sweetened with date fruit. The appearance of the bread samples decreased as the level of inclusion of the date fruit increased in the bread samples. In a similar manner, bread sweetened with wet date fruits had better appearance than bread samples sweetened with dried date. This may be attributable to surface smoothness of wet date fruit, as against the hard nature of dry date fruit. This observation was similar to the report of Manickavasagan et al. (2013) on the use of date as substitute for sugar in $i d l i$, a traditional food in India.

The results for the texture of the bread samples ranged between 8.00 to 8.30 . The results showed no significant $(\mathrm{P}>0.05)$ difference in the texture of the bread samples sweetened with 10 and $15 \%$ granulated sugar and date fruits. There was an increase in the preference of texture of bread samples, as the level of inclusion of date fruits and sugar increased. This indicated that the softness or the hardness of the bread samples depend on the level inclusion of the material added. There was no significant $(\mathrm{P}>0.05)$ difference in the taste of the bread samples sweetened withs granulated sugar and date fruit. This suggests that the sweet function of granulated sugar can be supplied by date fruit. The results from the taste indicated that date fruit can conveniently be used as substitute for granulated sugar as sweetener in bread making. The colour of the outer part of the bread samples is denoted as the crust colour. The crust colour of the bread samples ranged between 7.20 to 8.00 . Bread sweetened with granulated sugar was mostly preferred compared to the bread that were sweetened with date fruit. The brown may result from the pyrolysis of sugars in the bread samples. These results also indicated that the panelists preference of the crust colour increased as the level of inclusion increased from 5 to $15 \%$, which may suggest increase in the caramelization of sugar in the samples. Most bread consumers prefer to consume bread with brown crust colour, as it is one of the ways to identify bread that is well baked (Manickavasagan et al., 2013). The results of the overall acceptance of bread samples are shown in Table 4. Though the acceptance of the bread samples increased as the level of inclusion of the date fruit and the sugar increased, no significance $(\mathrm{P}>0.05)$ difference was observed among the samples, indicating that the use of either date fruit (wet or dry) or granulated sugar as sweetener in wheat bread were preferred in the same manners by the panellists. 


\section{Conclusion}

The study evaluated the potentials of date fruit as possible replacement for granulated sugar in wheat bread formulation. The study showed that addition of date fruit improved some important mineral elements of the final product and also improved the phenolic contents as well as the antioxidant properties of the date fruit enriched bread samples. The date fruit incorporated bread samples also exhibited better alpha amylase and glucosidase potentials than the bread that contained granulated sugar as sweetener. The nutritional composition of the date fruit was not significantly affected by the drying process and therefore, due to the extra production cost of the drying process, it may be suggested that the date be used in its fresh form by macerating and using it in the form of paste. Also, the sensory properties of the bread samples indicated that the use of date fruit as sweetener in bread did not negatively affect the overall acceptability of the bread samples while performing the role of sweetener in the final product. This study has revealed that the use of date fruit in bread served dual purpose as sweetener and as nutrient improver.

\section{Conflicts of Interest}

The authors declare that there is no conflict of interest in the submission and eventual publication of this work.

\section{References}

Al-Farsi M, Lee CY. 2008. Nutritional and functional properties of dates: A review. Critical Review in Food Science and Nutrition, 48: 877-884.

Ali A, Yusra M, Al-Said F. 2009. Chemical composition and glycemic index of 3 varieties of Omani dates. International Journal. of Food Science and Nutrition, 60(S4): 51-62.

Ameh MO, Gernah DI, Igbabul BD. 2013. Physico-chemical and sensory evaluation of wheat bread supplemented with stabilized undefatted rice bran. Journal of Food and Nutritional Science, 9: 43-48.

Anderson JW, Baird P, Davis RH, Ferreri S, Knudtson M, Koraym A, Waters V, Williams CL, 2009. Health benefits of dietary fiber. Nutrition Review, 67: 188-205.

Anyika JU, Uwaegbute AC. 2005. Frequency of consumption and nutrient content of some Snacks eaten by an adolescent secondary and University student in Abia State. Nigerian Journal of Nutritional Science, 26: 10-15.

AOAC. Official Methods of Analysis of the Association of Official Analytical Chemists, 20th ed, 2012.

Badifu SO, Chima CE, Ajayi YI, Ogori AF. 2005. Influence of Mango mesocarp flour supplement to micronutrient; physical and organoleptic qualities of wheat-based bread. Nigerian. Food Journal, 23: 59-68.

Benzie IFF, Strain JJ. 1999. Ferric reducing ability of plasma (FRAP) as a measure of antioxidant power: The FRAP assay. Analytical Biochemistry, 239: 70-76.

Bolarinwa IF, Aruna TE, Raji AO. 2013. Nutritive value and acceptability of bread fortified with moringa seed powder," Journal of the Saudi Society of Agricultural Science, 3:1-6.

Eong YJ, Hong FA, Tomas-Barberan A, Kader S, Alyson E. 2006. The flavonoid glycosideds and procynidine composition of Deglet Noor dates (Phoenix dactylifera). Journal of Agriculture and Food Chemistry, 54: 2405-2411.

Famuwagun AA, Taiwo KA, Gbadamosi SO, Oyedele DJ. 2016. Optimization of production of bread enriched with leafy vegetable powder. Journal of Food Processing and Technology, 7: 7 .
Girgih A, Udenigwe C, Li H, Adebiyi A, Aluko R. 2011. Kinetics of enzyme inhibition and antihypertensive effects of hemp seed (Cannabis sativa L.) protein hydrolysates. Journal of the American Oil Chemical' Society, 88: 1767-1774.

Gulcin I, Oktay M, Kirecci E, Kufrevioglu OI. 2003. Screening of antioxidant and antimicrobial activities of anise (Pimpinella anisum L.) seed extracts. Food Chemistry, 83: 371.

Guo C, Yang J, Wei J, Li Y, Xu J, Jing Y. 2003. Antioxidant activities of peel, pulp and seed fractions of common fruits as determined by FRAP assay. Nutrition Research, 23: 1719-1726.

Hamada J, Hashim I, Sharif F. 2002. Preliminary analysis and potential uses of date pits foods. Food Chemistry, 76(2):135137, http://dx.doi.org/10.1016/S0308-8146(01)00253-9

Ismail B, Haffar I, Baalbaki R, Mechref Y, Henry J. 2006. Physico-chemical characteristics and total quality of five date varieties grown in United Arab Emirates. International Food Science and Technology, 41: 919-926.

Ishurd O, Zahid M, Xiao P, Pan Y. 2004. Protein and amino acid contents of Libyan dates at three stages of development. Journal of Science of Food and Agriculture, 84: 481-484.

Johnson RK, Yon BA. 2010. Weighing in on added sugars and health. Journal of American Diet Association, 110:1296-1299.

Kim YM, Wang MH, Rhee HI. 2004. A novel alpha glucosidase inhibitor from pine bark Carbohydrate. Food Research, 339: 715-727.

Kranz, SH, Smiciklas-Wright AM, Mitchell D. 2005. Adverse effect of high added sugar consumption on dietary intake in American preschoolers. Journal of Pediatrics, 146:105-111.

Kwon Y, Apostolidis E, Shetty K. 2006. Inhibitory potential of wine and tea against alpha amylase and alpha glucosidase for management of hypertensive linked to type 2 diabetes. Journal of Food Biochemistry, 32:15-31.

Marwa AR. 2018. Consumer acceptance of orange juice mixed with water mint leave extract. Recent Patent on Food, Nutrition and Agriculture, 9: 50-54.

Manickavasagan A, Mathew TA, Al-Attabi ZH, Al-Zakwani IM. 2013. Dates as a substitute for added sugar in traditional foods - A case study with idli. Emirate Journal of Food Agriculture, 25 (11): 899-906 doi: 10.9755/ejfa. v25i11.14920 http://www.ejfa.info/

Nwosu JN, Owuamanam CI, Omeire GC, Eke CC. 2014. Quality parameters of bread produced from substitution of wheat flour with cassava flour using soybean as an improver. American Journal of Research Communication, 2(3): 99-180.

Odunlade TV, Famuwagun AA, Taiwo KA, Gbadamosi SO, Oyedele DJ, Adebooye OC. 2017. Chemical Composition and Quality Characteristics of Wheat Bread Supplemented with Leafy Vegetable Powders. Hindawi Journal of Food Quality 7 pages https://doi.org/10.1155/2017/9536716

Pathak D, Majumdar J, Raychaudhuri U, Chakraborty R. 2017. Study on enrichment of whole wheat bread quality with the incorporation of tropical fruit by-product. International Food Research Journal, 24(1): 238-246.

Pragati J, Sangita B, Singh K. 2017. Effect of nutritional, physiochemical and sensory properties on the development of bread with incorporation of wheat grass powder. International Journal of Food Science and Nutrition, 2(6): 109-114.

Sevindik M. 2020. Antioxidant activity of ethanol extract of Daedaleopsis nitida medicinal mushroom from Turkey. Mycopath, 16(2):47-49

Shahidi F, Naczk M. 2004. Phenolics in Foods and Nutraceuticals. Boca, Rotan, FL: CRC Press.

Sulaiman SF, Ooi KL. 2014. Antioxidant and $\alpha$-glucosidase inhibitory activities of 40 tropical juices from malaysia and identification of phenolics from the bioactive fruit juices of barring tonia race mosa and Phyllanthusacidus. Journal of Agriculture and Food Chemistry, dx.doi.org/10.1021/ jf502912t 
Vayalil PK. 2002. Antioxidant and antimutagenic properties of aqueous extract of Date fruit (Phoenix dactylifera L. Arecaceae). Journal of Agriculture and Food Chemistry, 50: $610-617(\mathrm{~s})$

World Health Organization, 2003. Food and Agriculture Organization of the United Nations Expert Consultation. Diet, nutrition and the prevention of chronic diseases. Technical Support Series 916. Geneva, Switzerland: World Health Organization
Wang H, Gao XD, Zhou GC, Cai L, Yao WB. 2008. In vitro and in vivo antioxidant activity of aqueous extract from Choerospondias axillaries fruit. Food Chemistry, 106: 888895.

Xie Z, Huang J, Xu X, Jin Z. 2008. Antioxidant activity of peptides isolated from alfalfa leaf protein hydrolysate. Food Chemistry, 111: 370-376. 